\title{
Vegetational Analysis Of Medicinal Plants Of Bharatpur Block, Dist-koria (Chhattisgarh) India
}

\section{Mantosh Kumar Sinha}

K.R. Technical College, Sarguja University, Ambikapur (Chhattisgarh) India

\begin{abstract}
The State of Chhattisgarh has about $44 \%$ of its geographical Area Covered with forests. The Koria district in Chhattisgarh lies between 22058' to 23049' North latitudes and 810 33' to 82045 ' East longitude. The average rainfall is $121.36 \mathrm{~cm}$. The forest area is $81.23 \%$ of Total dist. area. The annual mean temperature is $240 \mathrm{C}$. The temperature varies between $16.20 \mathrm{C}$ to $310 \mathrm{C}$. Geologically the area is dominated by upper Gondwana rocks. Which are rich in coal deposit. The highest mountain ranges of the region occupy the northern part of the district. The district Koria has a very rich flora exhibiting diversity specially of medicinal plants. There is no comprehensive description of the flora of the district is available. The district has a tribal population using enormous range of plants for their basic needs, sustenance and livelihood. "Keeping these points in view" the Present paper deals with diversity of the medicinal plants of the district and their ecological status. Vegetational analysis of Bharatpur block revealed some interesting observations on phytosociological characters enumerate medicinal plants belonging to Bharatpur block enumerate 80 medicinal plants were recorded. the common plant species showing maximum frequency were Tribulus terrestris (90\%), Vicia sativa (80\%) and Jatropha curcas, Cleome gynandra and Blumea lacera (70\%). At this block, Woodfordia fruticosa, Xanthium strumarium and Pergularia extensa were showing maximum frequency of $80 \%, 70 \%$ and $60 \%$ respectively. Woodfordia fruticosa showed high density also.

*Correspondence to Author: Anisur Dr. Mantosh Kumar Sinha, K.R. Technical Colleg, K.R. Technical College, Pt. Shivdhari Colony, Near Forest Office Pratappur Road, Ambikapur (C.G.)India

Email: sinha.mantosh80@gmail. com

$\mathrm{Ph}$ on e: 08518860388 ,09691610059.

\section{How to cite this article:}

Mantosh Kumar Sinha. vegetational analysis of MEDICINAL PLANTS OF BHARATPUR Block, distkoria (chhattisgarh) india. International Journal of Traditional and Complementary Medicine 2016;1(3): 0001-0008.

Published 10/14/2016.

eSciencePublisher

eSciPub LLC, Houston, TX USA. Website: http://escipub.com/
\end{abstract}


Triumfetta rhomboidea showed maximum density and abundance but Bacopa monnieri and Vanda roxburghii showed maximum abundance. It was abstracted that Bacopa monnieri, Costus speciosus, Curculigo orchioides, Curcuma amada and Embelia robusta were the rare species. They exhibited only $20 \%$ frequency. Leea macrophylla was also very rare having only $10 \%$ frequency and only density of 1 . Curculigo orchioides and Pterocarpus marsupium were among the less abundant species at this site.

Key Words: Phytosociology, Bharatpur, vegetation, \% frequency

\section{INTRODUCTION}

Koria district in Chhattisgarh is very rich in natural vegetation and biological wealth. The district lies between $22^{\circ} 58^{\prime}$ to $23^{\circ} 49^{\prime}$ North latitude and $81^{\circ} 33^{\prime}$ to $82^{\circ} 45^{\prime}$ 'East longitude and has a forest area of $81.23 \%$. Average rainfall is $121.36 \mathrm{~cm}$. and annual mean temperature is $24^{\circ} \mathrm{C}$. The district is dominated by Upper Gondwana rocks which are rich in deposition of coal. The vegetation particularly the forests have not been explored fully excepting a few reports from the forest department (Tiwari, 1992) [13] There is no report on the rich forest flora of the district. Keeping these points in view the present investigation was planned to enumerate phytosociological analysis of vegetation of medicinal plants belonging to Bharatpur block.

\section{METHODOLOGY}

The work required extensive field survey and therefore a thorough and extensive survey of the five blocks of the Koria district of Chhattisgarh was done during the years 2005 to 2008. Bharatpur block included study sites which were widely separated from each other, encompassing an area of $40 \mathrm{~km}^{2}$. Study sites were visited of frequent intervals and a thorough sampling was done to document the species diversity. The plant specimens were preserved, identified and a herbarium has been prepared. Identification of medicinal plants species was primarily done by gathering local information regarding availability and utilization of various wild medicinally important plants.

The sampling sites were selected randomly these are Masora, Jardol, Patwahi, Bhagwanpur, Badkadol, Jolgi, Kudra, Hatwari, Ghaghra, Belgawan, Bahrasi, Mainpur, Mannod, Khatoli, Umarwah, Titoli, Pandari, Semaria, Rend and Wadhvar. (Fig-1)

The phytosociological characters, such as, \% frequency, density and abundance were also recorded as per method described by Mishra (1968). [4]

\section{RESULTS \& DISCUSSION}

Phytosociological observations on medicinal plants belonging to Bharatpur block enumerated 80 medicinal plants were recorded. the common plant species showing maximum frequency were Tribulus terrestris $(90 \%)$, Vicia sativa (80\%) and Jatropha curcas, Cleome gynandra and Blumea lacera (70\%).

At this block, Woodfordia fruticosa, Xanthium strumarium and Pergularia extensa were showing maximum frequency of $80 \%, 70 \%$ and $60 \%$ respectively. Woodfordia fruticosa showed high density also. Triumfetta rhomboidea showed maximum density and abundance but Bacopa monnieri and Vanda roxburghii showed maximum abundance.

It was abstracted that Bacopa monnieri, Costus speciosus, Curculigo orchioides, Curcuma amada and Embelia robusta were the rare species. They exhibited only $20 \%$ frequency. Leea macrophylla was

also very rare having only $10 \%$ frequency and only density of 1 . Curculigo orchioides and Pterocarpus marsupium were among the less abundant species at this site. (Table -1)

However, the results clearly indicate a high degree of diversity and the community is a tropical dry deciduous type of Sal forest. Presently the medicinal plant diversity was also recorded as very high. There are plant species showing very low population density which draw attention of researchers for conservation. The sampled area requires conservation because of its potential for natural regeneration and utility value as well as varied plant diversity.

Adhikari et al. have analysed the composition, distribution and use pattern of medicinal trees of Uttaranchal State in different eco-regions. They have 
Table -1 Phytosociological observation of medicinal plants of BHARATPUR Block

\begin{tabular}{|c|c|c|c|c|c|c|c|}
\hline S.No. & Botanical Name & Frequency & Density Ab & bundance & Ecological & Distribution & \\
\hline & $\%$ & & Distribution & n $\quad \mathrm{R} / \mathrm{C}$ & & & \\
\hline 1. & Adhatoda vasica Nees. & $S$ & 40 & 6.2 & 15.5 & Seldom present & $\mathrm{R}$ \\
\hline 2. & Adina cordifolia Hook. f. & $\mathrm{T}$ & 30 & 2.3 & 7.6 & Seldom present & $\mathrm{R}$ \\
\hline 3. & Albizzia odoratissima Benth. & S & 50 & 17.3 & 34.6 & Often present & $\mathrm{R}$ \\
\hline 4. & Aristolochia indica L. & $\mathrm{H}$ & 30 & 3 & 10 & Seldom present & $\mathrm{R}$ \\
\hline 5. & Bacopa monnieri L. & $\mathrm{H}$ & 20 & 23.3 & 116.5 & Rare & C \\
\hline 6. & Barleria prionitis $\mathrm{L}$. & $\mathrm{H}$ & 50 & 9.8 & 19.6 & Often present & $\mathrm{R}$ \\
\hline 7. & Bauhinia purpurea $\mathrm{L}$. & $S$ & 40 & 8.5 & 21.25 & Seldom present & $\mathrm{R}$ \\
\hline 8. & Boswellia serrata Roxb. & $\mathrm{T}$ & 40 & 3.5 & 8.75 & Seldom present & $\mathrm{R}$ \\
\hline 9. & Bryophyllum calycinum Salis. & $\mathrm{H}$ & 60 & 40.3 & 67.1 & Often present & $\mathrm{C}$ \\
\hline 10. & Cannabis corniculata $\mathrm{L}$. & $S$ & 40 & 9.6 & 24 & Seldom present & $\mathrm{R}$ \\
\hline 11. & Cassia sophera L. & $S$ & 40 & 10.1 & 25.2 & Seldom present & $\mathrm{R}$ \\
\hline 12. & Chlorophytum tuberosum Baker. & $\mathrm{H}$ & 20 & 2.2 & 11 & Rare present & $\mathrm{R}$ \\
\hline 13. & Clerodendron serratum Spreng. & S & 30 & 5.3 & 13.2 & Seldom present & $\mathrm{R}$ \\
\hline 14. & Costus speciosus Smith & $\mathrm{H}$ & 20 & 5.9 & 29.5 & Rare & $\mathrm{C}$ \\
\hline 15. & Crinum asiaticum $\mathrm{L}$. & $\mathrm{H}$ & 30 & 2.6 & 8.6 & Seldom present & $\mathrm{R}$ \\
\hline 16. & Curculigo orchioides Gaertn. & $\mathrm{H}$ & 20 & 1.4 & 7 & Rare & $\mathrm{R}$ \\
\hline 17. & Curcuma amada Roxb. & $\mathrm{H}$ & 20 & 5.3 & 26.5 & Rare & $\mathrm{C}$ \\
\hline 18. & Curcuma aromatica Salisb. & $\mathrm{H}$ & 50 & 43.3 & 86.6 & Often present & $\mathrm{C}$ \\
\hline 19. & Cymbopogon flexuosus Hack. & $S$ & 20 & 2.8 & 14 & Rare & $\mathrm{R}$ \\
\hline
\end{tabular}




\begin{tabular}{|c|c|c|c|c|c|c|c|}
\hline 20. & Cymbopogon martini Stapf. & $\mathrm{H}$ & 50 & 68 & 136 & Often present & C \\
\hline 21. & Cyperus rotundus $\mathrm{L}$. & $\mathrm{H}$ & 40 & 42.9 & 107.2 & Seldom present & C \\
\hline 22. & Cyperus scariosus $\mathrm{Br}$. & $\mathrm{H}$ & 50 & 51.4 & 102.8 & Often present & C \\
\hline 23. & Dodonaea viscosa $\mathrm{L}$. & $\mathrm{H}$ & 60 & 42.1 & 70.16 & Often present & $\mathrm{C}$ \\
\hline 24. & Dryopteris crenata Christ. & $\mathrm{H}$ & 20 & 17 & 8.5 & Rare & $\mathrm{R}$ \\
\hline 25. & Embelia robusta Roxb. & $\mathrm{S}$ & 20 & 2.1 & 10.5 & Rare & $\mathrm{R}$ \\
\hline 26. & Erythrina indica Lamk. & $\mathrm{T}$ & 40 & 6.7 & 16.7 & Seldom present & $\mathrm{R}$ \\
\hline 27. & Eulophia campestris Wall. & $\mathrm{H}$ & 30 & 3.3 & 11 & Seldom present & $\mathrm{R}$ \\
\hline 28. & Euphorbia tirucalli L. & $\mathrm{S}$ & 50 & 17.5 & 35 & Often present & $\mathrm{R}$ \\
\hline 29. & Ficus hispida $\mathrm{L}$. & $\mathrm{T}$ & 50 & 4.2 & 8.4 & Often present & $\mathrm{R}$ \\
\hline 30. & Flemingia nana Roxb. & $\mathrm{H}$ & 50 & 11.5 & 23 & Often present & $\mathrm{R}$ \\
\hline 31. & Gloriosa superba L. & $\mathrm{S}$ & 30 & 2.6 & 8.66 & Seldom present & $\mathrm{R}$ \\
\hline 32. & Glossogyne pinnatifida DC & $\mathrm{H}$ & 30 & 3.7 & 12.33 & Seldom present & $\mathrm{R}$ \\
\hline 33. & Grevillea robusta A. Cunn. & $\mathrm{T}$ & 30 & 5.5 & 18.33 & Seldom present & $\mathrm{R}$ \\
\hline 34. & Grewia hirsuta Vanb. & $\mathrm{S}$ & 20 & 2.9 & 14.5 & Rare & $\mathrm{R}$ \\
\hline 35. & Holoptelea integrifolia Planch. & $\mathrm{T}$ & 30 & 3.2 & 10.66 & Seldom present & $\mathrm{R}$ \\
\hline 36. & Holarrhena antidysenterica Wall. & $\mathrm{T}$ & 30 & 7.5 & 25 & Seldom present & $\mathrm{R}$ \\
\hline 37. & Jatropha gossypifolia L. & $\mathrm{S}$ & 60 & 28 & 46.6 & Often present & $\mathrm{R}$ \\
\hline 38. & Jussiaea suffruticosa L. & $\mathrm{H}$ & 40 & 38.7 & 96.7 & Seldom present & $\mathrm{C}$ \\
\hline 39. & Lasiosiphon eriocephalus Decne & $\mathrm{H}$ & 20 & 0.8 & 4 & Rare & $\mathrm{R}$ \\
\hline 40. & Lawsonia inermis $\mathrm{L}$. & $\mathrm{S}$ & 50 & 51.1 & 102.2 & Often present & $\mathrm{C}$ \\
\hline
\end{tabular}




\begin{tabular}{|c|c|c|c|c|c|c|c|}
\hline 41. & Leea macrophylla Horn. & $\mathrm{S}$ & 10 & 01 & 10 & Rare & \\
\hline 42. & Lepidium sativum L. & $\mathrm{S}$ & 30 & 7.5 & 25 & Often present & $\mathrm{R}$ \\
\hline 43. & Leucas cephalotes Spreng. & $\mathrm{S}$ & 50 & 18.7 & 37.4 & Often present & $\mathrm{R}$ \\
\hline 44. & Martynia diandra Glox. & $\mathrm{S}$ & 60 & 9.5 & 15.83 & Often present & $\mathrm{R}$ \\
\hline 45. & Mimusops hexandra Roxb. & $\mathrm{T}$ & 20 & 2.7 & 13.5 & Rare & $\mathrm{R}$ \\
\hline 46. & Ocimum basilicum $\mathrm{L}$. & $\mathrm{H}$ & 50 & 22 & 44 & Often present & $\mathrm{R}$ \\
\hline 47. & Ougeinia dalbergioides Benth. & $\mathrm{T}$ & 40 & 10.5 & 26.25 & Seldom present & $\mathrm{R}$ \\
\hline 48. & Oxalis corniculata L. & $\mathrm{H}$ & 60 & 21.9 & 36.5 & Often present & $\mathrm{R}$ \\
\hline 49. & Oxystelma esculentum $\mathrm{Br}$. & $\mathrm{H}$ & 30 & 9.5 & 31.66 & Seldom present & $\mathrm{C}$ \\
\hline 50. & Paederia foetida $\mathrm{L}$. & $\mathrm{S}$ & 50 & 12.7 & 25.4 & Often present & $\mathrm{R}$ \\
\hline 51. & Pandanus odoratissimus Roxb. & $\mathrm{S}$ & 30 & 3.5 & 11.66 & Seldom present & $\mathrm{R}$ \\
\hline 52. & Passiflora incarnata L. & C & 30 & 2.3 & 7.66 & Seldom present & $\mathrm{R}$ \\
\hline 53. & Pergularia extensa N.E.Br. & C & 60 & 14.2 & 23.6 & Often present & $\mathrm{R}$ \\
\hline 54. & Phyllanthus niruri L. & $\mathrm{H}$ & 50 & 21.3 & 42.6 & Often present & $\mathrm{R}$ \\
\hline 55. & Pluchea lanceolata Oliver \& Hierno. & $\mathrm{S}$ & 40 & 5.1 & 12.75 & Seldom present & $\mathrm{R}$ \\
\hline 56. & Pongamia pinnata Pierre. & $\mathrm{T}$ & 40 & 3.4 & 8.5 & Seldom present & $\mathrm{R}$ \\
\hline 57. & Premna integrifolia $\mathrm{L}$. & $\mathrm{T}$ & 50 & 8.5 & 17 & Often present & $\mathrm{R}$ \\
\hline 58. & Prosopis spicigera L. & $\mathrm{T}$ & 20 & 0.9 & 9 & Rare & $\mathrm{R}$ \\
\hline 59. & Psoralea corylifolia DC & $\mathrm{H}$ & 50 & 8.3 & 16.6 & Often present & $\mathrm{R}$ \\
\hline 60. & Pterocarpus marsupium Roxb. & $\mathrm{T}$ & 30 & 2.2 & 7.33 & Seldom present & $\mathrm{R}$ \\
\hline 61. & Pueraria tuberosa DC & $\mathrm{C}$ & 30 & 3.3 & 11 & Seldom present & $\mathrm{R}$ \\
\hline
\end{tabular}




\begin{tabular}{|c|c|c|c|c|c|c|c|}
\hline 62. & Rauwolfia tetraphylla L. & $S$ & 20 & 3.5 & 17.5 & Rare & $\mathrm{R}$ \\
\hline 63. & Schleichera trijuga Willd. & $\mathrm{T}$ & 40 & 5 & 12.5 & Seldom present & $\mathrm{R}$ \\
\hline 64. & Shorea robusta Gaertn. & $\mathrm{T}$ & 90 & 95.9 & 106.5 & Constantlyl present & C \\
\hline 65. & Solanum indicum $\mathrm{L}$. & $S$ & 30 & 6.4 & 21.33 & Seldom present & $\mathrm{R}$ \\
\hline 66. & Spilanthes acmella $\mathrm{L}$. & $\mathrm{H}$ & 20 & 4.8 & 24 & Rare & C \\
\hline 67. & Stevia rebaudiana Bertoni. & $\mathrm{H}$ & 50 & 28 & 56 & Often present & C \\
\hline 68. & Terminalia belerica Roxb. & $\mathrm{T}$ & 40 & 6.5 & 16.25 & Seldom present & $\mathrm{R}$ \\
\hline 69. & Terminalia tomentosa W.\&A. & $\mathrm{T}$ & 60 & 6.8 & 11.33 & Often present & $\mathrm{R}$ \\
\hline 70. & Tribulus terrestris L. & $\mathrm{H}$ & 30 & 26.4 & 88 & Seldom present & C \\
\hline 71. & Triumfetta rhomboidea Jacq. & $\mathrm{H}$ & 40 & 56.5 & 141.2 & Seldom present & $\mathrm{C}$ \\
\hline 72. & Urginea indica Kunth. & $\mathrm{H}$ & 60 & 47.7 & 79.5 & Often present & $\mathrm{C}$ \\
\hline 73. & Vanda roxburghii $\mathrm{L}$. & $\mathrm{H}$ & 40 & 45.4 & 113.5 & Seldom present & $\mathrm{C}$ \\
\hline 74. & Vernonia anthelminticum Willd. & $\mathrm{H}$ & 50 & 45.7 & 91.4 & Often present & $\mathrm{C}$ \\
\hline 75. & Vernonia cinerea Less. & $\mathrm{H}$ & 40 & 9.3 & 23.25 & Seldom present & $\mathrm{R}$ \\
\hline 76. & Vicia sativa $\mathrm{L}$. & $\mathrm{C}$ & 50 & 28.9 & 57.8 & Often present & $\mathrm{C}$ \\
\hline 77. & Vitex negundo L. & $\mathrm{T}$ & 40 & 4.5 & 11.2 & Seldom present & $\mathrm{C}$ \\
\hline 78. & Wedelia calendulacea Less. & $\mathrm{H}$ & 50 & 13.5 & 27 & Often present & $\mathrm{R}$ \\
\hline 79. & Woodfordia fruticosa Kurz. & $\mathrm{S}$ & 80 & 59.3 & 74.12 & Mostly present & $\mathrm{R}$ \\
\hline 80. & Xanthium strumarium L. & $\mathrm{H}$ & 70 & 28.5 & 40.71 & Mostly present & $\mathrm{R}$ \\
\hline
\end{tabular}


concluded that $86 \%, 32 \%, 11 \%, 5 \%$ and $2 \%$ species are present in different regions. Out of these, 128 species are exclusively sub-tropical. [1] Suraj and Menon have enumerated phytosociological analysis of woody vegetation along an altitudinal gradation in Ponmudi hill, Trichur district, Kerala. They carried out vegetation analysis to study the density, basal area, IVI, dominance, diversity index and distribution pattern of species along an altitudinal gradation in Ponmudi hill of Thrissur forest division in Kerala. [7] Negi et al. have enumerated phyto-sociological studies of a traditional reserve forest, Thal Ke Dhar, Pithoragarh, Central Himalayas (India). They have documented phytosociological study in Thal Ke Dhar Sacred forest to understand the structure, regene-ration potential and conservation status. [5] Awasthi et al. have studied floral diversity of Bandhavgarh National Park with a phytosociological approach. They explored the value of wildlife habitats for wildlife species which is directly linked to the type and variety of plant communities and their conditions. [2] Sahu S.C. et.al carried out in tropical dry deciduous forest of Boudh district, Orissa. They inventoried a total of 187 species (trees 91 , shrubs 10 , climbers 12 and herbs 74) with in a four hectare sampled area. [8] Suresh et.al. have enumerate 67 species from disturbed area of Thaniparai hills and 72 species from undisturbed area of Sundaramahalingan hills under Grizzled Giant squirrel wildlife sanctuary forest of Virudhunagar district. They have reported 51 families from the two sites with 125 genera and 139 species. [9] Thakur et al. have reported Tectona grandis as dominant tree species in forest vegetation of Sagar district on the basis of I.V.I. Record of more phytosociological analysis on vegetation of different regions have also been reported and in all these studies emphasis has been given to vegetation as a whole. In present study, analysis has been done especially emphasizing medicinal plants. [12]

Bijalwan et al. have done phytosociological analysis of overstorey and understorey woody perennials alongwith aspects in Balandi watershed of mixed dry tropical forest in Chhattisgarh plain. They concluded that aspect plays an important role in the structure and dominance in the phytodiversity. [3]

Pokhariyal et al. have analysed the comparative studies on species richness, diversity and composition of Anogeissus latifolius mixed forest in Phakot and Pathari Rao watersheds of Garhwal Himalyas. They have compared the tree species richness in the two watersheds and revealed that distribution and species richness pattern in Phakot and Pathari Rao watersheds were more or less similar. A total of 87 spp. were recorded. [6]

Shameem et al. have studied to investigate the comparative assessment of edaphic factors and phytodiversity of herbaceous vegetation on seasonal basis spring (March to May), summer (June to August), autumn (September to November) and winter (December to February), at two different ecosystems in lower Dachigam National Park, Kashmir Himalaya. Phytosociological attributes of plant species were studied by randomly laying 25 quadrats of $1 \times 1 \mathrm{~m}^{2}$ size at both sites. The vegetation data recorded was quantitatively analysed for density, frequency and abundance. Plant diversity was evaluated using different diversity indices. [10]

Shaheen Hamayun et al. have Studied that Hindukush Himalayas $(\mathrm{HKH})$ is one of the world's richest biodiversity region hosting 4 global biodiversity hotspots, 60 ecoregions and 488 protected areas. the important endemic taxa Current study was undertaken to get information about alpine vegetation structure and community distribution in Karambar lake surroundings, North Pakistan at 4200 m.a.s.l. A total of 108 plant species belonging to 27 families were recorded. [11]

\section{CONCLUSION}

The result in the present study clearly show that the flora is very rich floristically which may be attributed to its varied topography and variation in climatic conditions. Species showing high frequency and low abundance were attributed to a status of Regular distribution and species showing low frequency and high abundance were attributed to a status of showing contagious distribution.

\section{REFERENCE}

[1] Adhikari, B.S., M.M. Babu, P.L. Saklani and G.S. Rawat, (2003) Medicinal trees of Uttaranchal State Distribution, use pattern and prospects for conservation, Indian Forester, 129(2) 2: 43-267.

[2] Awasthi K. ,Ajay, Ashish Dwivedi, Tripathi K.K.and Pushpendra Singh (2007) ,Assessing floral diversity of Bandhavgarh National Park: A phytosociological approach. Jou. of Trop. Forestry, 23(I \& II) 63-76.

[3]Bijalwan Swamy A. , S.L., Sharma, C.M., Sah V.K. and Singh R.K., (2009) Phytosociological analysis of overstorey and understorey woody 
perennials alongwith aspects in Balmdi watershed of mixed dry tropical forest in Chhattisgarh plain. Indian J. Trop. Biodiversity 17(1) : 47-57.

[4] Mishra R, (1968). Ecology Workbook. Oxford and IBH Publication Co., New Delhi. p. 244.

[5] Negi, Chandra S. and Sunil Nautiyal (2005). Phytosociological studies of a traditional reserve forest - Thal ke Dhar, Pithoragarh, Central Himalayas (India). Indian Forester 131(4): 519534.

[6] Pokhariyal P. , V. Naiathani, S. Dasgupta and N.P. Todaria (2009) "Comparative studes on species richness, diversity and composition of Anogeissus latifolius mixed forest in Phakot and Pathari Rao watersheds of Garhwal Himalaya", Curr. Sci. 97(9) : 1349-1355

[7] Suraj M.A. and. Menon A.R.R (2005),Phytosoci logical analysis of woody vegetation along an altitudinal gradation in Ponmudi hill, Trichur district, Kerala, South India. Jour. of Trop. Forestry 21(I\&II): 11-16.

[8] Sahu S.C. ., Dhal Sudhakar N.K., Reddy C., Pattanaik Chiranjibi and Brahmam M., (2007) phytosociological Study of Tropical dry deciduous forest of Boudh District, Orissa, India Research Journal of Forestry, (1) : 66-72

[9] Suresh S. ,N.Siva and. Muthuchelian K. (2008) ,Plant species diversity at Grizzled Giant Squirrel wild life sanctuary in Western Ghats of Tamilnadu the India J. Trop.Biodiversity 16 (2) : 125- 134.

[10] Shameem S. A. , and Kangroo Irfana N. ( 2011) "Comparative assessment of edaphic features and phytodiversity in lower Dachigam National Park ,Kashmir Himalaya, India" African Journal of Environ. Science and Technology $5,(11): 972-984$.

[11] Shaheen H. , Naseer Ahmad, Naveed Alam, Khalid Ahmed and Zahid Ullah(2011) ",Phytodiversity and endemic richness in high altitude Rama Valley, Western Himalayas, Northern Pakistan. Journal of Medicinal Plants Research Vol.5(8) : 1489-1493.

[12] Thakur A.S. and Khare P.K ( 2008) "Species Diversity and Composition of forest vegetation of Sagar district in Central India" The Indian Forester 134, (6 ) 801-813.

[13] Tiwari, P. (1992) , Working plan for Koria forest division Surguja Circle Chhattisgarh Forest Department Vol.-1. 